THURSDAY, SEPTEMBER 4, 1873

\section{THE TESTIMONIAL TO MR. COLE}

$A^{S}$ was to be expected, the subscriptions for the welldeserved testimonial to Mr. Cole, to which we have already referred, have so far been thoroughly satisfactory, upwards of 2,000 . having already been subscribed. Among the names of the subscribers will be noticed the names of men eminent in nearly every department of human activity. Thus we see Dr. De La Rue, Mr. Brassey, Mr. Baines, M.P., Messrs. Clowes and Son, Elkington and Co., Prof. Ella, Mr. C. J. Freake, Lord Ronald L. Gower, Sir Francis Grant, Earl Granville, Messrs. S. C. Hall, Hawkshaw, Hawksley, Lord Houghton, Messrs. H. A. Hunt, C.B., Jackson and Graham, John Kelk, Longmans, J. E. Millais, Lord C. Paget, Sir A. de Rothschild, Sir Titus Salt, Duke of Sutherland, Messrs. G. Trollope and Sons, Sir Richard Wallace, Dr. J. F. Watson, Marquis of Vestminster, Sir Joseph Whitworth, \&c. \&c. We may well hope that ere the list be closed many more names will be added, and such a sum subscribed as will render possible a testimonial worthy of the services performed by Mr. Cole to all the best interests of this country.

The earliest work which can be considered to have a connection with Science undertaken by $\mathrm{Mr}$. Cole, was the reform of the Patent Laws, which he advocated in 1850 , afterwards inducing the Society of Arts to take.up the subject. He wrote three Reports, and the principles which he laid down have been generally adopted as the basis of the present law. He particularly insisted upon the principle of a moderate fee at the first registration of an invention, such payment to increase at the option of the inventor in after years. He denounced all "taxes on inventions," as such, and public opinion is now beginning to go with him. Successive Governments have received hundreds of thousands of pounds from this source, and still withhold all proper aid to the encouragement of Science. There is a spice of sarcasm in the adage which has been worked in Sgraffito on the back wall of the new Science Schools, "Scientia non habet inimicum nisi ignorantem."

In $1852 \mathrm{Mr}$. Cole reformed, or we may almost say, established, the system of Art Schools, making it possible for every locality to have its Art School if it pleased. In 1853 the Department of Art was made Department of Science and Art, and Dr. Playfair was appointed to organise the Science division; but he shortly afterwards resigned his post, and became Professor of Chemistry at Edinburgh. Mir. Cole then became :sole Secretary for Science and Art. The late Marquis of Salisbury was the Lord President, and doubtless to the great interest which this nobleman took in all matters appertaining to Science is to be ascribed some of the success with which $\mathrm{Mr}$. Lowe was enabled to ventilate and carry out his views. Captain Donnelly, R.E., was invited to enter the Department, and through the instrumentality of Lord Salisbury, Mr. Cole, and Captain Donnelly the present Government system of scientific instruction throughout the country, one of the things of which England has the greatest reason to be proud, was evolved; and through the admirable harmony existing between Major Donnelly and Mr. Cole the work has been

No, 20I-Vor. virr. brought to its present flourishing condition. In 1856 there were 16 Science schools, in 1872 there were 1,238 . This is one part of the work which Mr. Cole has done fo English Science, and we blush to think that it has not been appreciated by men of Science as it ought to be and as it will be appreciated.

The Report which has just been issued by the Science and Art Department as to the attendance in the various classes connected with it, and the number of visito rs to the various museums during 1872 , will give some idea of the magnitude of the work accomplished by Mr. Cole.

The number of persons who have during the year 1872 attended the Schools and classes of Science and Art in connection with the Science and Art Department is as follows: viz. 36,783 attending Science Schools and Classes in 1872 , as against 38,015 in 1871 , and 244,134 receiving instruction in Art, showing an increase on the previous year of 31,633 , or nearly 15 per cent. At the Royal School of Mines there were 20 regular and 148 occasional, students ; at the Royal College of Chemistry, 212 studen's'; at the Metallurgical Laboratory, 30 ; at the Royal [School of Naval Architecture there were 35. At the Royal College of Science for Ireland there were 20 associate or regular students, and 19 occasional students. The lectures delivered in the lecture theatre of the South Kensington Museum were attended by I I,958 persons, or 2,927 more than in $187 \mathrm{I}$. The evening lectures to working men at the Royal School of Mines were attended by 2,400 persons; and 186 Science teachers attended the special course of lectures provided for their instruction in the new Science Schools at South Kensington. The various courses of lectures delivered in connection with the Department in Dublin were attended by 2,577 persons; and at the evening popular lectures, swhich were given in the Edinburgh Museum of Science and Art during the Session of $1871-2$, there was an attendance of 1,416 . The total number of persons, therefore, who received direct instruction as students, or by means of lectures, in connection with the Science and Art Department in 1872 , is nearly 299,000 , showing an increase as compared with the number in the previous year of 28,000 or 10 per cent. The museums and collections under the superintendence of the Department in London, Dublin, and Edinburgh, were last year visited by upwards of $2,922,000$ persons, showing the very considerable increase of $1,141, \infty 00$, or about 63 per cent. on the number in $187 \mathrm{I}$. The returns received of the number of visitors at the Local Art and Industrial Exhibitions, to which objects were contributed from the South Kensington Museum, show an attendance of upwards of 574,000 . The total number of separate attendances during thel year 1872 , as shown by the returns of the different Institutions and Exhibitions, in connection with the Department, has been upwards of $3,795, \infty 00$. This total, compared with that of the previous year, presents an increase of $1,117,000$, or 53 per cent., not including the number of visitors at local exhibitions, which was exceptionally augmented last year by the attendance of 420,000 at the Dublin Exhibition of Art and Industry, and is necessarily liable to much fluctuation from year to year.

We regret extremely to see that part of the great work done by Mr. Cole, in establishing the South Ken- 
sington Museum, runs some risk of being undone by the unintelligent intermeddling of Government. It would appear from statements recently made in the House of Commons that arrangements were being made for transferring the management of the South Kensington, Bethnal Green, and similar institutions to the trustees of the British Muscum. It is difficult for an outsider to sce what Government means by contemplating such a step; we believe no better means could be taken to cripple the efficiency of such institutions than by giving them over to the irresponsible management of the unpaid trustees of the British Museum, who have at present much work on their hands, which is the subject of constant Parliamentary inquiry. We cannot conceive that Mr. Cole would approve of any such step, a step which, we repeat, would be sure to mar the great work which, with untiring labour, all-conquering zeal, and advanced intelligence, he has accomplished. Report indeed has reached us that a National Committee is being formed to urge upon MIr. Gladstone's re-constituted Government the necessity of putting the British Museum, the National Gallery, and Institutions supported by Parliamentary funds, and now Trustee-muddled, under the direct control of a responsible Minister.

Sir Joseph Whitworth consulted Mr. Cole upon the establishment of Scholarships for Mechanical Science, to take place after his death. Mr. Cole recommended him to establish them during his life, so that he might have the enjoyment of watching the progress of them. Sir Joseph followed this recommendation, and presented the country with 3,000 l. a year for these Scholarships.

Mr. Cole is now devoting special attention to the application of Science to Productive Industry in the yearly International Exhibitions, and we trust that he may long be spared to reap the honour which is his due and to help on the work of which he has laid the foundation.

The erection in Exhibition Road of the handsome Science Schools, one of the few buildings devoted to Science of which the country may be justly proud, which Mr. Cole has at length successfully achieved, is due solely to the persistency of his efforts, rendered more and more pertinacious by the obstinacy and penuriousness of the Treasury, which in the most niggardly spirit is still starving the work and preventing its proper development, simply becsuse, we presume, it is a scientific work; and it was the intention of the recent Chancellor, Mr. Lowe, that in this particular England should be distanced by the smallest Continental or American state. It is fair to add that Mr. Cole was supported in this particular direction by the Duke of Buckingham, the Duke of Marlborough, and the Marquis of Ripon, who have successively been Lord Presidents since $\mathbf{1} 866$.

\section{ADVANCED TEXT-BOOK OF PHYSICAL GEOGKAPHY}

Advanced Text-Book of Physical Geography. By David Page, LL.D., F.G.S., Professor of Geology in the College of Physical Science, Newcastle. Second and Enlarged Ed. (Edinburgh and London: Blackwood, 1873.) DHYSICAL Geography is one of those branches of 1 knowledge which, without being a science in itself, makes use of many of the Sciences to explain and illus- trate the facts and phenomena with which it deals. So far as it is confined to the mere knowledge of facts and description of natural phenomena, no special acquaintance with any science is required; but when it comes to deal with the causes of phenomena and the deductions from geographical facts, it is essential that the teacher should himself possess a good general knowledge of several branches of modern Science. In particular it is necessary that he should clearly grasp the main principles of Physics, that he should have a good acquaintance with the distribution of animals and plants, and so much familiarity with arithmetic and mathematics as to be able to avoid making statements which are palpably incorrect.

After a careful examination of the present volume, we are forced to conclude that the author is, on all the abovementioned points, unfitted to teach this particular subject. It is with much regret that we say this, having expected something very different, not only from the popularity of Prof. Page as an author and a teacher, but also from the criticism of one of our first literary periodicals (used as an advertisement), that the work is "a thoroughly good text-book of Physical Geography." In order to justify this difference of opinion from so high an authority, it will be necessary to point out what are the most prominent errors and defects in the volume. Some of these defects may, it is true, be mere oversights ; but most persons will be of opinion that, in the second edition of an educational work, the plea of "oversight" can hardly be allowed.

In the second chapter - on the figure, motion, and dimensions of the earth - we find a scries of curious mis. conceptions, blunders, or obscurities. At page 19 we have the globe "revolving and rotating in obedience to the laws of gravitation and attraction," and in the next page these words are again used as implying distinct "forces." On page 21 occurs the following :- "But day and night are of unequal and varying length according to the seasons; and these seasonal successions are caused by the facts-first, that the orbit or path of the earth's revolution round the sun is not a perfect circle, but an ellipse; and second, that in performing this revolution her axis is not perpendicular, but inclined at an angle of $66^{\circ} 27_{4}^{x^{\prime}}$ to the plane of her orbit." This is simply absurd. The ellipticity of the earth's orbit has nothing whatever to do with the fact of there being seasons, which would occur exactly the same were the orbit a perfect circle. The actual effect of the elliptic orbit in slightly modifying the length and severity of winter in the two hemispheres, and which is of some importance as being an element in explanation of the cause of the glacial epoch, is never so much as alluded to. In a recent public examination some of the competitors gave this very account of the seasons, and received few or no marks in consequence. They had probably got up the subject from Dr. Page's volume. Three pages further we have a table of certain dimensions of the planets. This has no particular bearing on physical geography, but as it is given it should have been correct. It is, however, full of gross blunders, which can be detected by observation alone. We have in three columns-the diameter in miles, the cubic contents in miles, and the volume, earth being taken as $\mathrm{I}$. Now the "solid contents" and the "volume" being the same 